\title{
Policy in providing Guided Textbooks: Voice of Principals and Teachers
}

\author{
Asep Nurjamin ${ }^{1}$, Ninah Hasanah ${ }^{2}$, Ardi Mulyana ${ }^{3}$, Zainah Asmaniah ${ }^{4}$ \\ \{asep5nurjamin@gmail.com\} \\ Institut Pendidikan Indonesia, Jl. Pahlawan No.32 Sukagalih Tarogong Kidul, Garut, Indonesia
}

\begin{abstract}
Given that circular number 10/D/KR/2016, government's policy in giving guided textbooks for teachers, has been publicized, this study aims to scrutinize how this policy is perceived by headmasters and teachers. To achieve this purpose, interviews and questionnaires were used to collect the data, involving ten principals and ten teachers spread across ten sub-districts in the suburb of ASEAN region. The data were then analyzed inductively; coding, categorizing, analyzing, interpreting, and concluding. Seeing that positive perceptions are addressed to this policy, it is safe to say that the government is expected to consistently control this policy; that is, doing appraisal towards the quality of the textbook regularly by involving teachers as the practical users of the textbooks.
\end{abstract}

Keywords: policies, textbooks, perception

\section{Introduction}

In Indonesian context, The Ministry of Education and Culture through the Directorate General of Primary and Secondary Education has issued a circular number 10 / D / KR / 2016 [1]. This concerns on provision of textbooks for the 2016/2017 curriculum for the implementation of the 2013/2017 academic year. This addresses the heads of provincial education offices and heads of education district offices throughout Indonesia. Each school can determine its own textbook according to its assessment. The catalogue of books to be purchased has been provided by the government in the electronic system book (BSE) by accessing the site https://e-katalog.lkpp.go.id/backend/buku_kurikulum_2013.

This policy will likely affect the system of procurement and circulation of books in schools. The school does not need to search for the book itself. Parents also do not need to be bothered with the budget for buying books for their children. Now, textbooks are provided by the school utilizing money from school operational costs.

However, complaints from several parties are also appear, especially from schools and teachers who consider such procurement system of books will be hampered by the complexity of bureaucratic networks that often become obstacles. One of the problems that became a concern was the delay in the procurement of books as happened in the procurement of educational report books. These complaints should be taken into account to the textbook evaluation. In addition to this, the teachers' point of view also is very valuable to investigate. This is parallel to [2], stating that teachers have authority to be involved in assessing textbook due to their major role as the practical guide of the textbook usage.

Numerous related studies have been undertaken. One of them was a study conducted by [3], investigating students' perceptions on the textbooks provided in the library. This study was 
conducted in one of senior high schools in Bandung. This quantitative research with questionnaires as the instruments reveal that students gave positive appraisal towards the content quality and the delivery of the textbook. Therefore, this study recommended schools; including teachers, librarian, and headmaster, cooperate to develop the use of textbooks in the school. Another study was also undertaken to see teachers' perception on English Textbook [4]. Two English teachers served as the research participants. The data were collected qualitatively through interview, questionnaires, and observation. The result of this study reveal that teachers assumed that this textbook suited to the students' need and characteristics. However, there were some problems encountered by them; one of them is the difficulty level of the textbook's materials. A study done in emphasizing teachers belief and point of view towards an English Textbook [5]. This study, followed by two English techers in a Senior High School in Central java, employed questionnaires, interview, and non-participant observation to collect the data. As a main result, the teachers believe in the importance of the synchronization between the textbook and the teaching materials.

From the reports above, most of previous studies concerned in evaluating textbook from the perspective of students and teachers. Such studies in gaining insights and point of view are assumed important since it could potentially influence the practice and attitude in doing a particular action [6]. Hence, it is necessary to do further research with more comprehensive scope; that is, involving teachers and one of stakeholders; that is principal. Hence, this study is an attempt to investigate the perceptions of headmasters and teachers on the government's policy in providing the guided textbooks.

\section{Method}

This qualitative study collected the data through interviews to ten school principals and ten teachers who were considered representative in spreading across the local educational stakeholders in Garut Kota District, Cilawu District, Tarogong Kaler District, Tarogong Kidul District, Samarang District, and Bayongbong District, Karangpawitan District, Wanaraja District, Wanaraja District, District Leles, and Kadungora District. Schools chosen in each subdistrict are the best qualified schools according to the supervisors' assessments in each subdistrict.

From each school one teacher and one headmaster were assigned as the research sample. The principal is sampled because of his authority in procuring textbooks in his school while the teacher is determined as a sample because the teacher is the party using the textbook in learning. The principal was interviewed using five closed questions and two open questions about the procurement of textbooks. The teachers were asked to fill out a questionnaire containing ten questions about the contents of the textbook. Interviews and filling out questionnaires were carried out in the principal's room at recess.

\section{Results and Discussion}

This phase elaborates the results from interview as well as questionnaires. The results of the interview indicated that 70 percent of principals stated that this policy had felt helpful. This centralized book procurement has reduced his work in selecting and defining textbooks that will be used in his school. After the enactment of this government policy, principals do not have to 
be preoccupied with the arrival of book sellers almost from every publisher who usually comes in turns every day to offer their books. In terms of the quality of the book, the principal is not worried because all the books offered in the BSE catalogue are believed to have gone through a profound review process so that fear of mistakes in choosing books is gone. Concerns about fraud from irresponsible publishers will not happen again because in essence the publisher's reliability has been tested by the government through careful verification.

In response to this, a previous study [7] points an idea that electronic book can be an alternative to use in teaching and learning process since it could provide multiple context, completed by some multimodal features. This is assumed positive to use in classroom setting since it could stimulate students' engagement in the learning activity. Moreover, the discussion of textbook always becomes an interesting topic since it is claimed very important in teaching learning process. Even, it is stated that every technology could not be able to diminish the role of textbook [8].

As the result from questionnaires, it was shown that the teachers who were respondents answered satisfied with the books they chose. In terms of the accuracy in procurement, they stated that the book had been received by the teachers in time so that the textbook could be directly used since the first days of school. In terms of content, the teachers stated that the contents of the book were in accordance with the 2013 revised edition of the curriculum content.

In terms of appearance, the book has been displayed in an interesting form and may be of interest to students. According to the teachers, the layout of the contents has been quite good and interesting. Learning material has been arranged according to proper sequencing using principles from simple to complex. Training and assignments have been provided proportionally. The language in the textbook has shown a high level of readability. In addition, there were no errors in writing and spelling.

The response towards new textbook as explained above was also confirmed by some research findings across countries. Like in Bangladesh, a study [9] shows that there was disjointedness between new policy in designing guided textbook and the pedagogical practice. It is shown by the activities in the textbook offered were not equivalent to the context of the country. In Indonesia context, a previous study with the focus of analysing math teachers towards 2013 curriculum based textbook was undertaken in Banda Aceh Province. This qualitative study results in positive point of view towards this book since it contains cultural and character value, building students' behaviour. However, they did agree that there were some contents which should be revised [10]

The responses from the teachers above give valuable depiction to the implementation of the textbook since teachers' attitude will have great influence to the way they use the textbook. [11]

\section{Conclusions}

From the results of the study, it can be concluded that the level of satisfaction of principals on government policies, especially regarding the enactment of circular letter number 10 / D / KR / 2016 concerning the provision of textbooks for implementing schools for the 2013/2017 Academic Year 2016/2017 curriculum is very high, reaching eighty-seven percent. The results of research on teachers about their satisfaction with the books that have been set by the government and selected by the school have shown a high level of satisfaction, which reached seventy-eight percent. Although both types of respondents have shown high satisfaction, both 
the principal and the teacher added a number of notes. Among them, from the school principal. They stated that not all selected books were available in sufficient quantities. One of the first titles chosen turned out that the stock was stated to have run out. Finally, some principals chose the available books not based on the expected quality. This phenomenon also implicitly implies that the quality of books offered is not balanced.

\section{Implication}

Positive perceptions as shown by headmasters and teachers on the policy indicate that the government should be persistent and consistent in implementing this policy. It means that providing guided textbook for teachers should be gradually followed up by the firm controlling. One of them is through regular appraisal of the textbook usage, particularly teachers as the practical users of the textbook itself.

\section{References}

[1] Direktorat Jenderal Pendidikan Dasar dan Menengah. Surat edaran nomor 10/D/KR/2016 tentang penyediaan buku teks pelajaran bagi sekolah pelaksana Kurikulum 2013 tahun Pelajaran 2016/2017. (2016).

[2] Tok, H.: TEFL textbook evaluation: From teachers' perspective. Educational study and review. Vol 5., pp. 508-517 (2010).

[3] Rachmawati, G.: buku teks pelajaran sebagai sumber belajar siswa di perpustakaan sekolah SMAN 3 Bandung. Edulib. Vol. 5., pp. .(2015)

[4] Diniah, S.N.: Teachers' perceptions towards the use of english textbook in EFL Classroom. Journal of English and Education. Vol 1, pp.72-81 (2013)

[5] Rosyida, E.:Teachers' perceptions towards the use of English textbook. Jurnal tardis Bahasa inggris. Vol.9., pp. 43-54 (2016)

[6] Donaghuea, H.: an instrument to elicit teachers' belief and assumptions. ELT Journal. Vol. 57., pp. 344-350 (2003)

[7] Oliveira, J, Camacho, M, \& Gisbert, M.: exploring student and teacher's perceptions of E-textbooks in a primary school. Comunicar. Vol. 42., pp. 1-14 92014)

[8] Callison, D. : Textbook. School library media activities monthly. Vol. 19., pp. 31-40 (2003)

[9] Farooqui, S.: teachers ' perceptions of textbook and teacher's guide: a study in secondary education in Bangladesh. The journal of ASIA TEFL. Vol. 5., pp. 191-210 (2008) 
[10] Darius, S.: persepsi guru terhadap materi matematika di buku guru dan buku siswa kelas IV, V, Vi pada kurikulum 2013 di gugus delima kota banda aceh. Jurnal pesoka dasar.Vol. 2., pp. 57-64 (2014)

[11] Mc.Grath, I.: teachers` and learners` images for coursebooks. ELT journa. Vol. 60., pp. 171-180 (2006) 